\title{
Chronic Heart Failure management program
}

\author{
G Musca*, o Cuccurullo \\ From de Senectute: Age and Health Forum \\ Catanzaro, Italy. 5-7 December 2009
}

\section{Background}

Chronic Heart Failure (CHF) is one of the most remarkable health problems because of its prevalence (up tol $2 \%$ in west countries), morbidity and mortality. CHF is a disease of the elderly: approximately $80 \%$ of the patients hospitalized with $\mathrm{CHF}$ are more than 65 years old. CHF has a strong impact in terms of social and economic effects: very frequent hospital admissions and a significant increase of medical costs.

CHF elderly patients demand an effective and integrated disease management program, because in these patients the following are present: Poor self-care, High prevalence of comorbidities (COPD, diabetes,hypertension, anaemia, renal dysfunction, cancer), High prevalence of diastolic heart failure, Polypharmacy, Physical and cognitive limitations (Difficult transfers to the hospital), Inadequate social support and social isolation, Depression and anxiety, High incidence of precipitating factors, Poor education, Poor compliance to therapy (pharmacological and not), Need of frequent reassessments [1].

\section{Management program [2,3]}

Elderly patients with concomitant diseases (the patient himself and his family are considered as active users)

Personnel Multidisciplinary team providing specialized follow-up: Nurse (responsible for education and followup), Specialist (internist, geriatrician, cardiologist), Dietician, psychologist, social assistant.

Primary care physician: Telephone follow-up and improved communication

Methods: Home assistance, improved communication (Easy and frequent telephonic contacts)

Interventions: Patients and family education, Diet counseling, Therapy adjustment, Increase in compliance to diet and therapy, Intensive follow-up for early detection and treatment, Episodes of WHF, Concomitant diseases (e.g. infections).

UO Medicina Interna, ASP Cosenza, Presidio Ospedaliero di Cetraro, Italy
Aims: Reduction in the incidence of hospitalizations, Improvement in the clinical course/quality of life, Reduction in management costs.

Published: 19 May 2010

\section{References}

1. Cuccurullo O, Musca F, Musca G: Scompenso cardiaco congestizio: frequenza e valore prognostico delle cause precipitanti. "Cuore Amico" Periodico di informazione e divulgazione scientifica di Cardiologia Riabilitativa e Preventiva. 2005, 1.

2. Musca F, Cauteruccio MA, Cuccurullo O, D'Alessandro A, Donadio D, Musca G: Integrated Pilot Study (IPS). alla ricerca di un modello efficace per la gestione del malato con S.C.C. Progetto Pilota Integrato con un Gruppo di Medici di Medicina Generale;. "Cuore Amico" Periodico di informazione e divulgazione scientifica di Cardiologia Riabilitativa e Preventiva. 2005, 1.

3. Consensus Conference: Il percorso assistenziale del paziente con scompenso cardiaco. Giornale Italiano di Cardiologia 2006, 7:383-432.

doi:10.1186/1471-2318-10-S1-A86

Cite this article as: Musca and Cuccurullo: Chronic Heart Failure management program. BMC Geriatrics 2010 10(Suppl 1):A86.
Submit your next manuscript to BioMed Central and take full advantage of:

- Convenient online submission

- Thorough peer review

- No space constraints or color figure charges

- Immediate publication on acceptance

- Inclusion in PubMed, CAS, Scopus and Google Scholar

- Research which is freely available for redistribution

Submit your manuscript at www.biomedcentral.com/submit
Ciomed Central 